\title{
IDENTIFICATION OF THREE STRAINS OF Entomopathogenic bacteria Isolated FROM Culex spp. LARVAE AND THEIR POTENCY ON Culex pipiens LARVAE.
}

Ahmed, R. A.

Economic Entomology Department, Faculty of Agriculture, Mansoura University, Mansoura, 35516, Egypt.

\begin{abstract}
Biological control alone or as a part of integrated vector management stands to be a better alternative to the chemical controls aimed against pest mosquitoes. Here, A screening for microorganisms that can be utilized as new host cells for mosquito larvicides was carried out. As persistence in the environment is required of host cells, the bacterial populations in mosquitoes collected from natural breeding ponds around Mansoura University was examined. Bacterial sequences were isolated using standard 16S rRNA gene sequencing. Bacillus species, especially Lysinibacillus sphaericus were found to be the dominant species and toxic to Culex larvae, Bacillus amyloliquefaciens was the second highly effect against culex larvae, $B$. amyloliquefaciens was isolated from Culex larvae for the first time in Egypt. Cellulosimicrobium cellulans also isolated and had the lowest effect. Detection and isolation of these bacteria offer a potential biocontrol mechanism as they possess high potential as novel host cells for application in mosquito control.
\end{abstract}

\section{INTRODUCTION}

Due to environmental conditions and mosquito resistance to several insecticides it is now paramount to find new control methods to control mosquito and mosquito borne diseases. So, at the present time, for the comprehensive control of insects, environmentally friendly pesticides together with biological control agents are strongly recommended (Federici et al., 2007 and Lacey, 2007). Lysinibacillus sphaericus (Meyer and Neide) is an aerobic mesophilic spore-forming bacterium that has been used with great success in mosquito control programs worldwide (Charles et al., 1996). Mosquitocidal activity of $L$. sphaericus and the persistence of its spores in the environment would make this species a suitable candidate for inoculation of mosquito breeding sites as an effective and ecologically friendly biological control agent (Mulla et al., 1984 and Siegel et al., 2001).

The mosquitocidal metabolite produced by the Bacillus amyloliquefaciens was found to kill both larval and pupal stages of mosquitoes. Hence, the inventory of mosquito biocontrol agents is now augmented with yet another bacterial agent that can serve as a potent candidate in the wake of resistance development to the already available bacterial mosquitocides (Geetha et al., 2011).

We decided to work in a more bio-control approach and assess what larvicide bacteria where present in Egyptian mosquito larvae. Identification of such bacteria, naturally surviving and affecting these populations would be the start of new engineering projects to minimise mosquito nesting, proliferation and would therefore impact of mosquito-borne diseases. 


\section{MATERIAL AND METHODS}

\section{Samples collection}

Mosquito larvae samples were collected from two different ponds around Mansoura University during June, July, August and September of 2011, samples were collected weekly during the four successive months. Samples were putted in plastic jars and transferred to the laboratory in plastic containers with water from the same site to separate larvae of Culex spp. Mosquito species were identified by their morphological characteristics, the dead larvae were sterilized by first placing them in sterile distilled water for 20 -s followed by two 20-s washes with $70 \%(\mathrm{v} / \mathrm{v})$ aqueous alcohol and a final 20-s wash with sterile distilled water. They were then homogenized in $10 \mathrm{ml}$ sterile physiological saline solution according to Días et al. (1992).

\section{Isolation of entomopathogenic bacteria from mosquito larvae samples}

The larvae were manually crushed with $10 \mathrm{ml}$ of sterile water. The suspension was shacked well for $10 \mathrm{~min}$ to homogenise and then serially diluted in sterile water to $10^{-6}$. Extracts were plated on nutrient agar media. After incubation at $30 \pm 1^{\circ} \mathrm{C}$ for 2 days, plates were examined and the developed colonies were subcultured on nutrient agar plates for purification. After incubation for 2 days, the purified bacterial colonies were transferred into nutrient agar slants for maintenance until subsequent tests. Nutrient agar medium was $(\mathrm{g} / \mathrm{l})$ : peptone 5.0; beef extract 3.0 agar 20.0 and $\mathrm{pH}$ was 7.0. This medium was used for maintenance of all isolates. All cultures were cultivated on nutrient agar for $48 \mathrm{~h}$ at $28^{\circ} \mathrm{C}$. A heat fixed smear was stained with malachite green and counter stained with fuchsin. The slide was observed under bright field microscopy with a $100 \times$ oil immersion objective (Holt et al., 1994).

Evaluation of the pathogenic potentials of the bacterial isolates on $C$. pipiens

\section{1- Rearing of Culex pipiens under laboratory conditions}

Rearing of $C$. pipiens in the laboratory was carried by the method described by Singh et al. (1972), Shams El-Dean (1982) and Abou Bakr (1984).

\section{2- Preparation of the bacterial inoculums}

The bacterial growths on the nutrient agar slants were scraped, using $5 \mathrm{ml}$ sterile tap water, then transferred to a flask containing $50 \mathrm{ml}$ sterile nutrient broth (Elcin, 1995). The resulting cell suspensions was calculated using plate count agar method according to Post (1988). The inocula were prepared using this suspension and were adjusted to $10^{6}, 10^{5}$ and $10^{4} \mathrm{CFU} / \mathrm{ml}$ (colony forming unit) by dilution with sterile tap water (Collins et al., 2003).

\section{3- Pathogenicity test}

Ten larvae of each larval instars $\left(2^{\text {nd }}, 3^{\text {rd }}\right.$, and $\left.4^{\text {th }}\right)$ of reared $C$. pipiens were placed in each concentration $\left(10^{6}, 10^{5}\right.$ and $\left.10^{4}\right)$ of the prepared bacterial suspension in rearing units $(20 \times 9 \times 7 \mathrm{~cm})$. Each treatment was replicated four times. Additional four rearing units of each mosquito larval instars were used without bacterial inoculum as a control. The mortality of the mosquito larvae were assayed after 12, 24, 36, 48, 60 and 72 hours. 


\section{4- Identification of the entomopathogenic bacteria}

A molecular approach based on the amplification and sequencing of the 16S rRNA gene was used for identifying the bacteria selected from the larvae as follow:

\section{DNA extraction and amplification}

DNA was extracted from the cultures using the GenElute Bacterial Genomic DNA kit (Sigma Aldrich, UK) as per the manufacturer's instructions, with the addition of lysozyme.

Approximately $10-15 \mathrm{ng}$ of template DNA was used in a $25 \mu \mathrm{L}$ PCR reaction mixture containing: $2 \mathrm{U}$ of Taq DNA polymerase (New England BioLabs, UK), 1X PCR ThermoPol buffer (2.0mM Tris- $\mathrm{HCl}$, 1.0mM (NH4) SO4, 1.0mM KCL) (New England BioLabs, Uk), 2.5mM deoxynucleoside triphosphate mix (Biogene, Cambs, UK), $0.25 \mathrm{mM}$ of both universal bacterial primers $27 \mathrm{~F}$ and $1525 \mathrm{r}$.

Amplified products were purified using the GenElute PCR purification kits (Sigma Aldrich), according to manufacturer's instructions. Cleaned PCR fragments were sequenced in both directions (GTAC Biotech, UK) and subsequently reassembled for full gene coverage.

16S rRNA gene sequencing analyses

$16 S$ rRNA gene sequence were aligned manually with corresponding sequences derived from a BLAST search, retrieved from the DDBJ/EMBL/GenBank databases, using the PHYDIT program (http://plaza.snu.ac.kr/ jchun/phydit/). Phylogenetic trees were inferred using the least-squares (Fitch and Margoliash 1967), maximum-likelihood (Felsenstein 1981) and neighbour-joining (Saitou and Nei, 1987) tree-making algorithms from the PHYLIP package (Felsenstein, 1993). Evolutionary distance matrices were generated for the least-squares and neighbour-joining methods, as described by Jukes and Cantor (1969). The resultant unrooted tree topologies were evaluated by bootstrap analyses (Felsenstein, 1985) based on 1000 resampling's of the neighbour-joining dataset, using the SEQBOOT and CONSENSE options from the PHYLIP package.

\section{Statistical analysis}

For selecing the most potant strain and suceptable larval stage proc ANOVA in SAS was used (Anonymous, 1988). Mean separation of the obtained results was conducted using Duncan's multiple range in the same program.

The effectiveness of the different treatments was conducted using Propit analysis of obtained data. Results were using LDP line program expressed in terms of $L T_{50}$ values at $95 \%$ fiducial limits. Slopes of regression lines were represented. Statistical analysis of the obtained data were made based on Probit analysis of Finney (1971).

\section{RESULTS AND DISCUSSION}

Identification of the entomopathogenic bacteria:

In this study, three species of bacteria from culex larvae, Bacillus amyloliquefaciens, Lysinibacillus sphaericus and Cellulosimicrobium cellulans were isolated and identified (Figures1\&2). The entomopathogenic 
bacteria, Bacillus amyloliquefaciens was isolated from Culex larvae for the first time in Egypt.

These results are similar to those of Wraight et al. (1987) for $L$. sphaericus and different target species of Culex . In india, Geetha et al., 2011 listed Bacillus amyloliquefaciens for the first time as a mosquito larvicidal activity against larvae of Anopheles stephensi,Culex quinquefasciatus and Aedes aegypti.

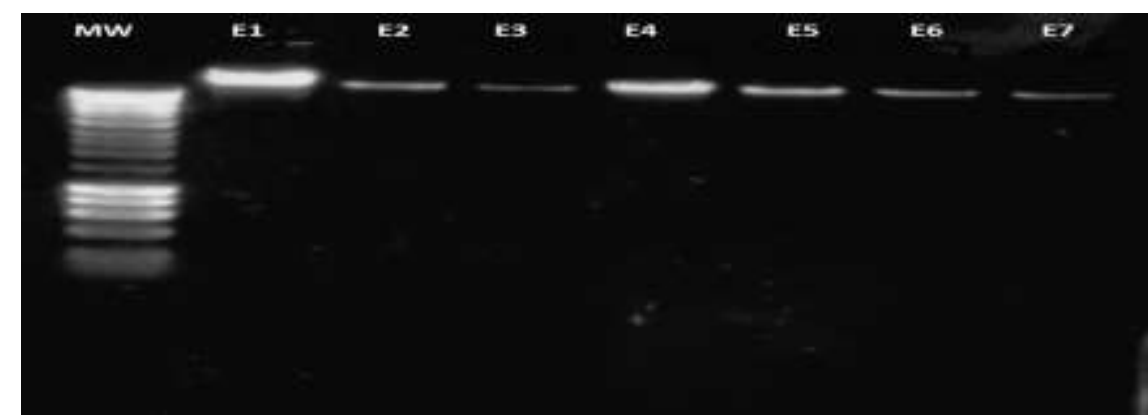

Figure 1. Genomic DNA extraction of the seven bacterial cultures isolated from mosquitos collected from natural breeding ponds around Mansoura University, Egypt.

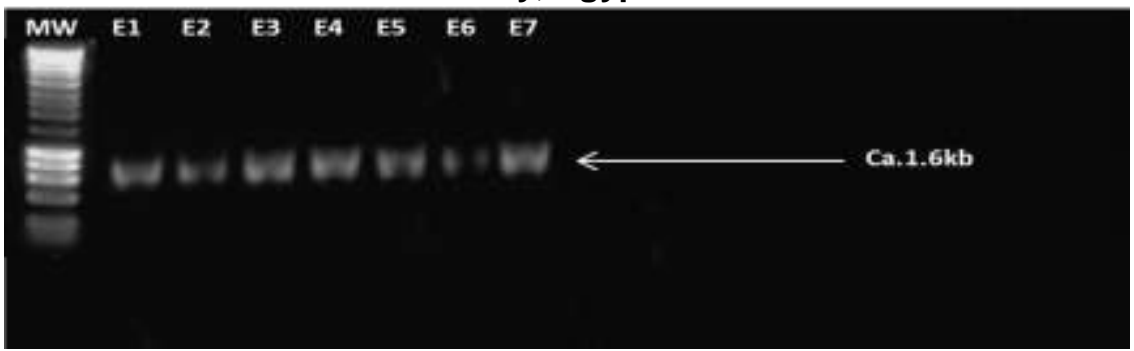

Figure 2. Representative PCR amplification of the seven genomic extracts, targeting the 27F-1525r region of the 16S rRNA gene sequence. The arrow indicates the size of the fragment being approximately $1.6 \mathrm{~kb}$.

\section{Pathogenicity test:}

Results of applying dose-mortality as log-probit model is presented in tables (1, 2 \& 3 ) and graphically illustrated in figures(3, $4 \& 5)$.

After $12,24,36,48,60$ and 72 hours the calculated $L T_{50}$ values were shown in table $1,2 \& 3$ and graphically illustrated in fig.3, 4 \& 5 . The mortality of the Culex pipiens $\left(2^{\text {nd }}, 3^{\text {rd }} \& 4^{\text {th }}\right.$ instar larvae) exposed to the different concentrations of bacerial strain showed that the most active bacerial was Lysinibacillus sphaericus. The Culex pipiens was found susceptible to $L$. sphaericus infection. Besides, as the concentrations of the bacerial increased, the Culex pipiens morality was also increased. This is due to smaller slope for the most active bacerial used compared with other ones. This means that speed of effect is concentration dependant but efficacy is not concentration dependant. These results are in complete accordance with those previously. 
Statistical analysis showed that there was signifecant differeance in the effecincy between [investigated three strains (Bacillus species, especially Lysinibacillus sphaericus were found to be the dominant species and toxic to Culex pipiens, Bacillus amyloliquefaciens was the second highly effect and Cellulosimicrobium cellulans also isolated and had the lowest effect), larval stage (the third instar larval was more suseptable than the senod and fourth instar larvae), concentrations (the $10^{6}$ concentration was more toxic effect than $10^{5}$ and $10^{4}$ on larvae stage and time mortality.

Table (1): Values of $\mathrm{LT}_{50}, \mathrm{LT}_{90}$ and slopes for the tested Lysinibacillus sphaericus versus $2^{\text {nd }}$ instar larvae of $C$. pipiens.

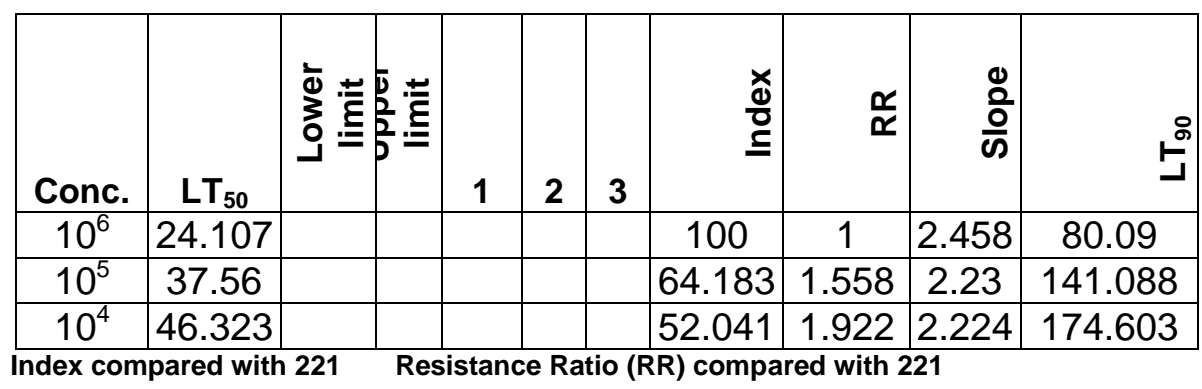

Table (2): Values of $\mathrm{LT}_{50}, \mathrm{LT}_{90}$ and slopes for the tested Lysinibacillus sphaericus versus $3^{\text {rd }}$ instar larvae of Culex pipiens.

\begin{tabular}{|c|c|c|c|c|c|c|c|c|c|c|}
\hline Conc. & LT50 & 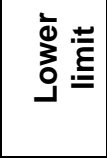 & 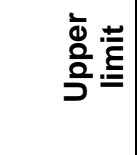 & 1 & 2 & 3 & 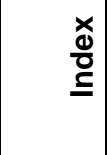 & $\stackrel{\mathbb{r}}{\boldsymbol{\alpha}}$ & $\frac{\text { 응 }}{\text { ம }}$ & 욤 \\
\hline $10^{6}$ & 19.904 & & & & & & 100 & \begin{tabular}{|l|}
1 \\
\end{tabular} & 2.218 & 75.285 \\
\hline $10^{5}$ & 22.254 & 18.023 & 26.063 & & * & & 89.44 & 1.118 & 1.712 & 124.805 \\
\hline $10^{4}$ & 36.888 & 32.141 & 42.298 & & & * & 53.958 & 1.853 & 1.799 & 190.295 \\
\hline
\end{tabular}

Table (3): Values of $\mathrm{LT}_{50}, \mathrm{LT}_{90}$ and slopes for the tested Lysinibacillus sphaericus versus $4^{\text {th }}$ instar larvae of Culex pipiens.

\begin{tabular}{|c|c|c|c|c|c|c|c|c|c|c|c|}
\hline Conc. & $\begin{array}{c}\text { Line } \\
\text { name }\end{array}$ & $\mathbf{L T}_{\mathbf{5 0}}$ & $\begin{array}{c}\text { Lower } \\
\text { limit }\end{array}$ & $\begin{array}{c}\text { Upper } \\
\text { limit }\end{array}$ & $\mathbf{1}$ & $\mathbf{2}$ & $\mathbf{3}$ & Index & $\mathbf{R R}$ & Slope & $\mathbf{L T}_{\mathbf{9 0}}$ \\
\hline $10^{6}$ & 421 & 58.933 & 46.9 & 115.945 & $*$ & & $*$ & 100 & 1 & 2.09 & 241.797 \\
\hline $10^{5}$ & 422 & 95.439 & & & & & & 61.749 & 1.619 & 1.566 & 628.014 \\
\hline $10^{4}$ & 423 & 124.012 & 92.373 & 212.143 & $*$ & & $*$ & 47.522 & 2.104 & 1.67 & 725.8 \\
\hline
\end{tabular}

Index compared with $421 \quad$ Resistance Ratio (RR) compared with 421 
Ahmed, R. A.

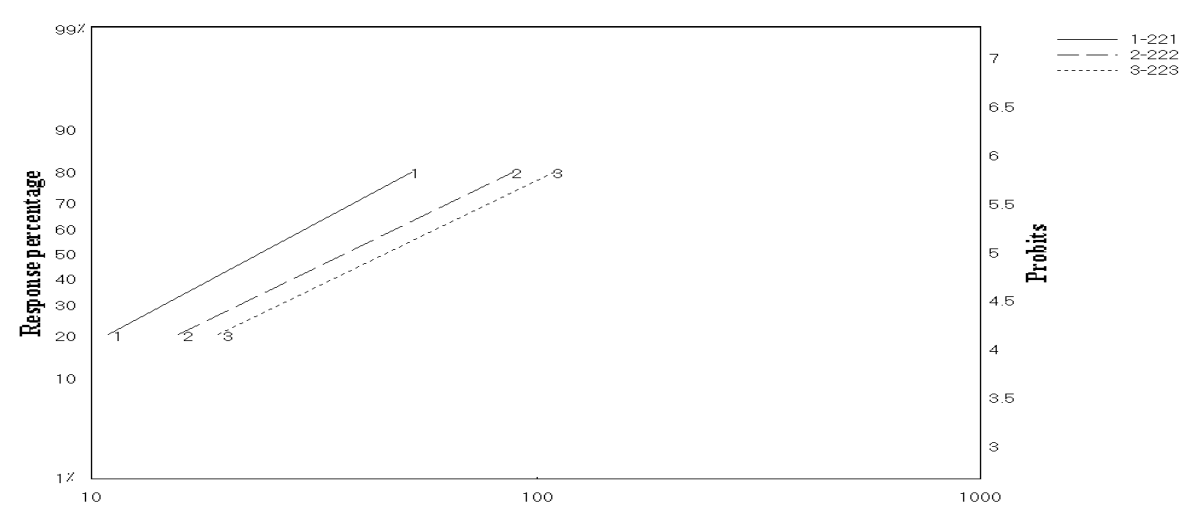

Log time (Days)

Figure 3. LT lines for the tested Lysinibacillus sphaericus concentrations versus $2^{\text {nd }}$ instar larvae of $C$. pipiens

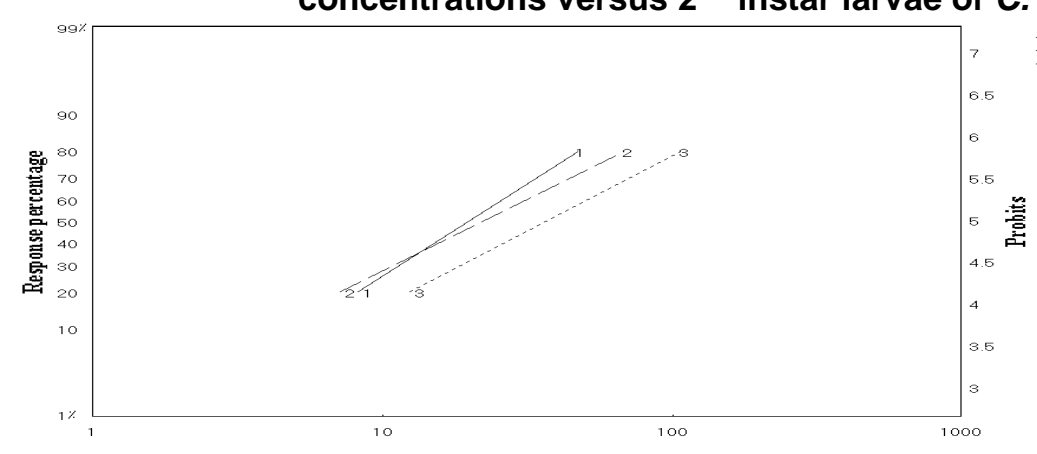

Log time (Days)

Figure 4. LT lines for the tested Lysinibacillus sphaericus concentrations versus $3^{\text {rd }}$ instar larvae of $C$. pipiens.

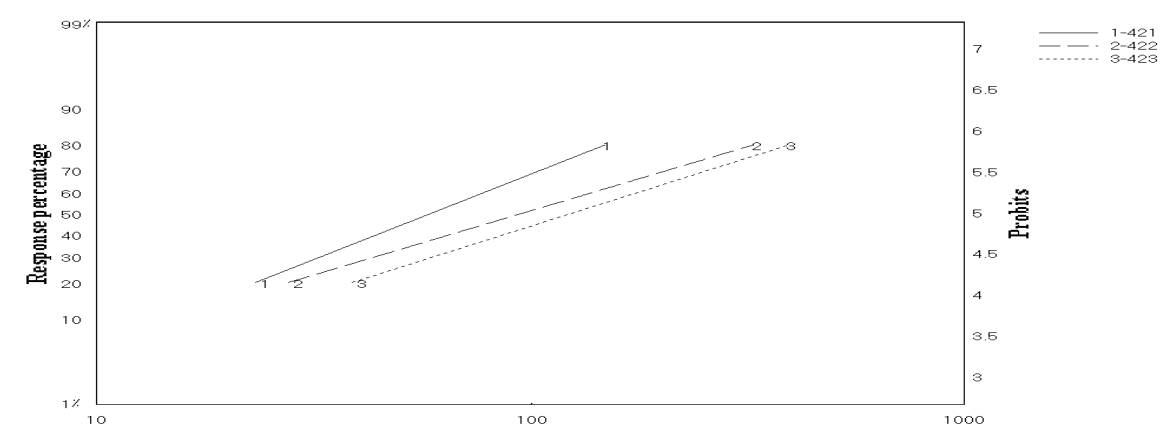

Log time (Days)

Figure 5. LT lines for the tested Lysinibacillus sphaericus concentrations versus $4^{\text {th }}$ instar larvae of $C$. pipiens 
These results are similar to those of Porter et al., 1993 and Vaidyanathan and Scott (2007) who recorded that some strains of $L$. sphaericus are toxic towards mosquito larvae and are used in the biological control of the vectors of malaria, filariasis, dengue fever and West Nile fever. Also, Federici et al. (2006 and 2007) regarded L. sphaericus as a toxic species against Anopheles immature stages. Tranchida et al., 2011 reported that the toxicity of $L$. sphaericus against immature stages of mosquitos results from the expression of the binary toxins $(41.9$ and $51.4 \mathrm{kDa})$ encoded by the binA and binB genes, which are loci expressed at the start of sporulation. The presence of both gene products comprising this toxin is necessary to produce mortality in mosquito larvae (Broadwell et al., 1990; Thanabalu et al., 1992 and Davidson et al.,1990). Another toxin of $100 \mathrm{kDa}$, called Mtx, is present in L. sphaericus strains of both low and high toxicity. The study of 16S rRNA gene sequences by Nakamura (2000) indicated that the L. sphaericus species is a heterogeneous taxon formed by seven groups. The high larval toxicity found in some $L$. sphaericus strains, such as 2362 (Weiser, 1984) and IAB59 (de Barjac et al., 1988), has led to the commercial use of these strains as biopesticides against populations of mosquitos.

The effects of bacteria, Bacillus amyloliquefaciens on mosquito larvae was recorded in india by Geetha et al., 2011 who reported that hemosquitocidal metabolite produced by this bacteria was found to kill both larval and pupal stages of mosquitoes. B. amyloliquefaciens is known to occupy a variety of terrestrial sites due to the versatility of the enzymes it secretes. Strains of $B$. amyloliquefaciens have been known for the production of cellulase and restriction enzyme BamH1 (Dubinina et al., 1983 and Lee et al., 2008). Strains of $B$. amyloliquefaciens are reported for the production of cyclic lipopeptides viz., surfactin, fengycin and bacillomycin D (Lee et al., 2007; Ramarathnam et al., 2007 and Chen et al., 2009a, 2009b). The cyclic lipopeptide, surfactin which is a powerful biosurfactant, produced by $B$. subtilis subsp. subtilis has been reported to be mosquitocidal (Geetha et al., 2010 and Geetha \& Manonmani, 2010).

Cellulosimicrobium cellulans had very small effect on mosquito larvae because it infest mosquito larvae accidentally, this bacteria also isolated from males of Aedes albopictus as reported by Moro et al., 2013.

\section{ACKNOWLEDGMENT}

I would like to acknowledge the cooperation of staff members of Microbiology Department, Faculty of Agriculture, Mansoura University for helping in isolation of entomopathogenic bacteria and preparation of the bacterial inoculums. I also like to thank members of Faculty of Health and Life Science, Northumbria University, UK, for helping in identification of the entomopathogenic bacteria and for the laboratory facilities provided. 


\section{REFERENCES}

Abou Bakr, H.E. (1984). Studies on certain biological control agents of mosquitoes in Egypt. Ph.D Thesis, Fac. Agric., Cairo Univ. 243 pp.

Anonymous (1988) SAS/STAT User's Guide, Ver. 6.03. SAS Institute Inc., Cary, North Carolina, $22 \mathrm{pp}$.

Broadwell, A.H., Baumann, L. and Baumann, P. (1990). The 42- and 51kilodalton mosquitocidal proteins of Bacillus sphaericus 2362: construction of recombinants with enhanced expression and in vivo studies of processing and toxicity. J. Bacteriol., 172(5):2217-2223.

Charles, J.F., Nielsen-LeRoux, C. and Delécluse, A. (1996). Bacillus sphaericus toxins: molecular biology and mode of action. Annu. Rev. Entomol., 41:451-472.

Chen, X.H., Koumoutsi, A., Scholz, R. and Borriss, R. $\left(2009_{b}\right)$. More than anticipated production of antibiotics and other secondary metabolites by Bacillus amyloliquefaciens FZB42. J. Mol. Microbiol. Biotechnol., 16:14-24.

Chen, X.H., Koumoutsi, A., Scholz, R., Schneider, K., Vater, J., Sussmuth, R., Piel, J. and Borriss, R. (2009a). Genome analysis of Bacillus amyloliquefaciens FZB42 reveals its potential for biocontrol of plant pathogens. J. Biotechnol., 140: 27-37.

Collins, D.P., Jacobsen, B.J. and Maxwell, B. (2003). Spatial and temporal population dynamics of a phyllosphere colonizing Bacillus subtilis biological control agent of sugar beet Cercospora leaf spot. Biological control, 26: 224-232.

Davidson, E.W., Oei, C., Meyer, M., Bieber, A.L., Hindley, J. and Berry, C. (1990). Interaction of the Bacillus sphaericus mosquito larvicidal proteins.Can J Microbiol., 36: 870-878.

de Barjac, H., Thiery, I., Cosmao-Dumanoir, V., Frachon, E., Laurent, P., Charles, J.F., Hamon, S. and Ofori, J. (1988). Another Bacillus sphaericus serotype harbouring strains very toxic to mosquito larvae: serotype H6. Ann Inst Pasteur Microbiol., 139(3):363-377.

Días, J.M.C.S., Gomes Monnerat, R. and Silva-Werneck, J.O. (1992). Aulas prácticas de bacteriología. In: Segundo curso de Controle Microbiano de Insetos. Brasilia. Brasil. pp 23.

Dubinina, G.P., Basnak'ian, I.A., Tsvetkova, N.V., Semina, I.E. and Tarasov, A.V., (1983). Isolation of the specific endonuclease BamH1 in the multicyclic cultivation of Bacillus amyloliquefaciens. Zh. Mikrobiol. Epidemiol. Immunobiol., 12-17.

Elcin, Y.M. (1995). Bacillus sphaericus 2362 - Calcium alginate microcapsules for mosquito control. Enzyme Microbiol Technol., 17: 587-591.

Federici, B.A., Park, H.W. and Sakano, Y. (2006). Insecticidal protein crystals of Bacillus thuringiensis. In: Shively JM (ed) Microbiology monographs series, Volume I. Inclusions in Prokaryotes. Springer, Berlin, 195-236. 
Federici, B.A., Park, H.W., Bideschi, D.K., Wirth, M.C., Johson, J.J., Sakano, Y. and Tang, M. (2007). Developing recombinant bacteria for control of mosquito larvae. In: Floore TG (ed) Biorational control of mosquitoes, vol 7. American Mosquito Control Association, 164-175.

Felsenstein, J. (1981). Evolutionary trees from DNA sequences: a maximum likelihood approach. J Mol Evol., 17:368-376.

Felsenstein, J. (1985). Confidence limits on phylogenies: an approach using the bootstrap. Evolution, 39:783-791.

Felsenstein, J. (1993). PHYLIP (Phylogenetic Inference Package), version 3.5c Department of Genetics. University of Washington, Seattle, USA.

Finney, D.J. (1971). Probit Analysis. (3rd edition, Cambridge University Press, Cambridge, 318 pp).

Fitch, W.M. and Margoliash, E. (1967). Construction of phylogenetic trees: a method based on mutation distances as estimated from cytochrome $c$ sequences is one of general applicability. Science 155:279-284.

Geetha, I. and Manonmani, A.M. (2010). Surfactin: a novel mosquitocidal biosurfactant produced by Bacillus subtilis ssp. subtilis (VCRC B471) and influence of abiotic factors on its pupicidal efficacy. Lett. Appl. Microbiol., 51: 406-412.

Geetha, I., Manonmani, A.M. and Paily, K.P. (2010). Identification and characterization of a mosquito pupicidal metabolite of a Bacillus subtilis subsp. subtilis strain. Appl. Microbiol. Biotechnol., 86: 17371744.

Geetha, I., Manonmani, A.M. and Prabakaran, G. (2011). Bacillus amyloliquefaciens: A mosquitocidal bacterium from mangrove forests of Andaman \& Nicobar islands, India. Acta Tropica, 120: 155- 159.

Holt, J.G., Murray, R.G.E., don Brenner, J., Bryant, M.P., Krieg, N.R., Moulder, J.W., Pfennig, N., Sneath, P.H.A., Staley, J.T. and Williams, S.T. (1994). Bergey's Manual of Determinative Bacteriology, $6^{\text {th }}$ edn., Journal of Endocrinology, 142(1): 171-179.

Jukes, T.H and Cantor, C.R. (1969). Evolution of Protein Molecules. New York: Academic Press, 21-132.

Lacey, L.A. (2007). Bacillus thuringiensis serovariety israelensis and Bacillus sphaericus for mosquito control. In: Floore TG (ed) Biorational control of mosquitoes, Bull. № 7. J Am Mosq Control Assoc., 23(2):133-163.

Lee, S.C., Kim, S.H., Park, I.H., Chung, S.Y. and Choi, Y.L. (2007). Isolation and structural analysis of bamylocin A, novel lipopeptide from Bacillus amyloliquefaciens LP03 having antagonistic and crude oilemulsifying activity. Arch. Microbiol., 188: 307-312.

Lee, Y.J., Kim, B.K., Lee, B.H., Jo, K.I., Lee, N.K., Chung, C.H., Lee, Y.C. and Lee, J.W. (2008). Purification and characterization of cellulase produced by Bacillus amyoliquefaciens DL-3 utilizing rice hull. Bioresour. Technol., 99: 378-386.

Moro, C.V., Florence, H.T., Fara, N.R., Pierre, R. and Patrick, M. (2013). Diversity of culturable bacteria including Pantoea in wild mosquito Aedes albopictus. BMC Microbiology, 13:70. 
Mulla, M.S., Darwazeh, H.A., Davidson, E.W. and Dulmage, H.T. (1984). Efficacy and persistence of the microbial agent Bacillus sphaericus againts mosquito larvae in organically enriched habitats. Mosq News, $44: 166-173$.

Nakamura, L.K. (2000). Phylogeny of Bacillus sphaericus-like organisms. Int J Syst Evol Microbiol., 50:1715-1722.

Porter, A.G., Davidson, E.W. and Liu, J.W. (1993). Mosquitocidal toxins of bacilli and their genetic manipulation for effective biological control of mosquitoes. Microbiol Rev., 57:838-861.

Post, F.J. (1988). . A laboratory manual for food microbiology and biotechnology. Star Publishing Co., Belmont, CA.

Ramarathnam, R., Bo, S., Chen, Y., Fernando, W.G., Xuewen, G. and de Kievit, T. (2007). Molecular and biochemical detection of fengycinand bacillomycin D-producing Bacillus spp., antagonistic to fungal pathogens of canola and wheat. Can. J. Microbiol., 53: 901-911.

Saitou, N. and Nei, M. (1987). The neighbor-joining method: a new method for constructing phylogenetic trees. Mol Biol Evol., 4:406-425.

Shams El-Dean, M.M. (1982). Utilization of the nematode, Romanomermis culicivorax in the biological control of some mosquito species. M.Sc. thesis, Fac.Agric., Cairo Univ. 150pp.

Siegel, J.P., Smith, A.R. and Novak, R.J. (2001). Recovery of commercially produced Bacillus thuringiensis var. Israelensis and Bacillus sphaericus from tires and prevalence of bacilli in artificial and natural containers. J Am Mosq Control Assoc., 17:33-41.

Singh, K.R.P., Patterson, R.S., LaBrecque, G.C. and Razdan, R.K. (1972). Mass rearing of Culex fatigans. WHO/VBC/72.386, $26 \mathrm{pp}$.

Thanabalu, T., Hindley, J. and Berry, C. (1992). Proteolytic processing of the mosquitocidal toxin from Bacillus sphaericus SSII-1. J Bacteriol., 174(15):5051-5056.

Vaidyanathan, R. and Scott, T.W. (2007). Geographic variation in vector competence for West Nile virus in the Culex pipiens (Diptera: Culicidae) complex in California. Vector Borne Zoonotic Dis., 7(2):193-198. doi:10.1089/vbz.2006.0589.

Wraight, S.P., Molloy, D.P. and Singer, S. (1987). Studies on the culicine mosquito host range of Bacillus sphaericus and Bacillus thuringiensis var. israelensis with Notes on the Effects of temperature and instar on bacterial efficacy. J Invertebr Pathol., 49:291-302. 


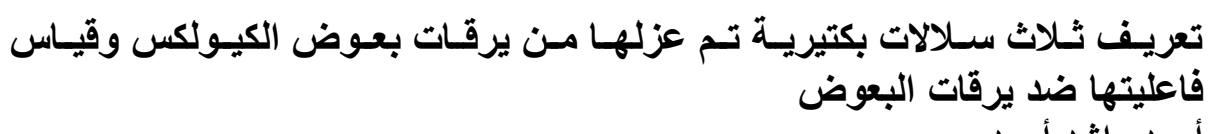

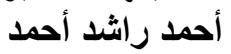

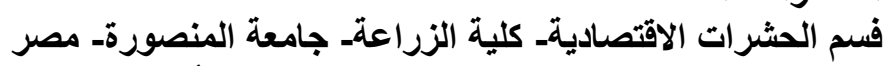

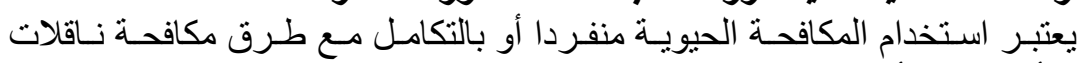

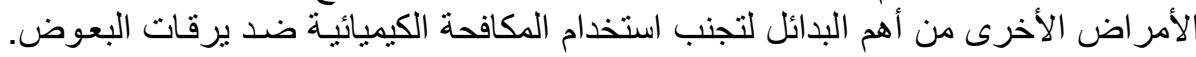

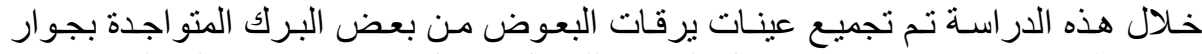

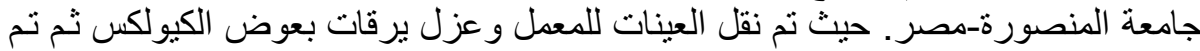

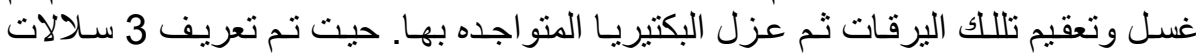

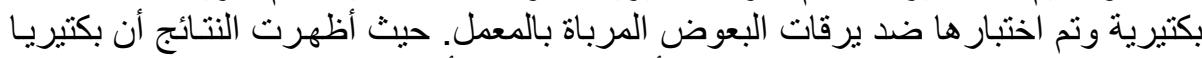

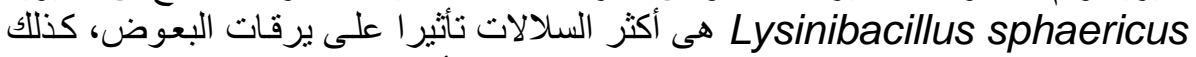

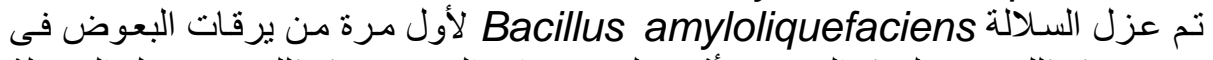

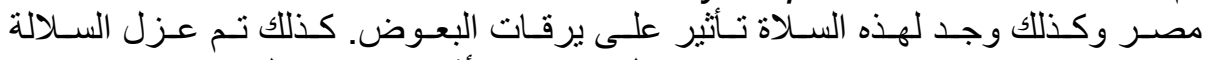
Cellulosimicrobium cellulans

كلية الزراعة - جامعة المنصورة كلية الزراعة - جامعة دمياط
قام بتحكيم البحث

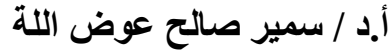

أ.د /حافظ عبد الرحمن القاضى عوضى 